\title{
Apolipoprotein E lipoprotein particles inhibit amyloid- $\beta$ uptake through cell surface heparan sulphate proteoglycan
}

Yuan Fu ${ }^{1,3}$, Jing Zhao ${ }^{1}$, Yuka Atagi ${ }^{1}$, Henrietta M. Nielsen ${ }^{1}$, Chia-Chen Liu ${ }^{1,2}$, Honghua Zheng ${ }^{1,2}$, Mitsuru Shinohara ${ }^{1}$, Takahisa Kanekiyo ${ }^{1 *}$ and Guojun $\mathrm{Bu}^{1,2^{*}}$

\begin{abstract}
Background: The accumulation, aggregation and deposition of amyloid- $\beta(A \beta)$ peptides in the brain are central to the pathogenesis of Alzheimer's disease (AD). Alzheimer's disease risk increases significantly in individuals carrying one or two copies of $A P O E \varepsilon 4$ allele compared to individuals with an $\varepsilon 3 / \varepsilon 3$ genotype. Growing evidence has demonstrated that apolipoprotein $E$ (apoE) strongly influences $A D$ pathogenesis by controlling $A \beta$ aggregation and metabolism. Heparan sulphate proteoglycans (HSPGs) are abundant cell surface molecules that bind to both apoE and $A \beta$. HSPGs have been associated with $A \beta$ aggregation and deposition. Although several lines of research have shown that apoE influences $A \beta$ clearance in the brain, it is not clear how apoE influences HSPG-mediated cellular uptake of $A \beta$.
\end{abstract}

Results: In this study, we show that apoE lipoprotein particles from conditioned media of immortalized astrocytes isolated from human APOE-targeted replacement (TR) mice significantly suppress cellular Aß42 and Aß40 uptake through cell surface HSPG. ApoE3 and apoE4 particles have similar binding affinity to heparin, while apoE4 particles are likely hypolipidated compared to apoE particles. We also found that the apoE particles antagonize A $\beta$ binding to cell surface, and inhibited $A \beta$ uptake in a concentration-dependent manner in Chinese hamster ovary (CHO) cells. While the effect was not apoE isoform-dependent, the suppressive effect of apoE particles on A $\beta$ uptake was not observed in HSPG-deficient CHO cells. We further demonstrated that apoE particles reduced the internalization of $A \beta$ in mouse primary neurons, an effect that is eliminated by the presence of heparin.

Conclusions: Taken together, our findings indicate that apoE particles irrespective of isoform inhibit HSPGdependent cellular A $\beta$ uptake. Modulating the ability of apoE particles to affect A $\beta$ cellular uptake may hold promises for developing new strategies for AD therapy.

Keywords: Aß, apoE, HSPG, Alzheimer's disease, Cellular uptake

\section{Background}

The accumulation and deposition of amyloid- $\beta$ (A $\beta)$ peptides composed of 40 or 42 amino acids in the brain are thought to be central events in the pathogenesis of Alzheimer's disease (AD) [1-4], the most common form of neurodegenerative dementia in the elderly [5]. The interaction of soluble $A \beta$ forms, in particular oligomers, with cell surface receptors initiates a toxic cascade,

\footnotetext{
*Correspondence: kanekiyo.takahisa@mayo.edu; bu.guojun@mayo.edu Yuan Fu and Jing Zhao are co-first authors.

'Department of Neuroscience, Mayo Clinic, Jacksonville, FL, USA

Full list of author information is available at the end of the article
}

leading to subsequent neurodegeneration and cognitive dysfunction [6]. On the other hand, neurons can also internalize and efficiently degrade toxic species of $A \beta$ and eliminate these from the brain [7]. Thus, it is critical to understand how $\mathrm{A} \beta$ interacts with cell surface receptors and how these events impact $A \beta$ aggregation, toxicity and/or metabolism.

The $\varepsilon 4$ allele of the $A P O E$ gene encoding the apolipoprotein $\mathrm{E}$ (apoE) protein strongly influences $\mathrm{AD}$ risk and age of onset $[8,9]$; risk increases significantly in individuals carrying one copy $(\varepsilon 2 / \varepsilon 4$, OR $2.6 ; \varepsilon 3 / \varepsilon 4$, OR 3.2$)$ or two copies $(\varepsilon 4 / \varepsilon 4$, OR 14.9$)$ of the $\varepsilon 4$ allele compared to 
individuals with an $\varepsilon 3 / \varepsilon 3$ genotype [10, 11]. Importantly, the occurrence of cortical $A \beta$ deposition is increased already at early middle-age in asymptomatic APOE \&4 carriers $[12,13]$ and an age-dependent increase in $A \beta$ deposition in the brains has been proposed as a pathobiological phenotype of APOE ع4 [14]. While apoE plays a critical function in lipid transport in the brain [15], apoE also directly or indirectly influences $A \beta$ aggregation, cellular uptake, and metabolism [16, 17]. For example, apoE was shown to protect primary human pericytes and astrocytes from toxicity induced by $A \beta 40$ harboring the Dutch mutation [18]. Cellular uptake of oligomeric versus fibrillar forms of $A \beta 42$ is also altered by apoE in cultures of primary human astrocytes and microglia $[19,20]$. Whether an apoE-mediated reduction in A $\beta$-uptake is beneficial or harmful is not clear; however, co-administration of apoE and $A \beta 42$ increased the gene expression of the $A \beta$-degrading enzyme neprilysin in primary astrocytes isolated from post-mortem brain tissue from non-demented subjects [21]. Despite these pieces of evidence, whether interaction between apoE and $A \beta$ represents a major pathway under physiological or pathophysiological conditions is not fully understood. Previous studies have suggested that apoE forms complexes with $A \beta[6,9]$ via both the receptor-binding region in the $\mathrm{N}$-terminal domain and the lipid-binding region in the $\mathrm{C}$-terminal domain $[9,22]$. Interestingly, these $A \beta$-binding regions within apoE overlap with the heparin-binding regions $[23,24]$. Of note, epitope mapping reveals that residues $13-17$ in $A \beta$ are common sites that interact with both apoE and heparin [22, 25]. However, a recent report showed that only a small portion of $\mathrm{A} \beta$ interacts with apoE lipoprotein particles in solution under physiological conditions [26]. The same study also reported the ability of apoE lipoprotein particles to compete with $A \beta$ for cellular uptake via the low-density lipoprotein receptor-related protein 1 (LRP1) in astrocytes. Importantly, increasing the lipidation of apoE4 was recently suggested to alleviate cognitive impairment and $\mathrm{A} \beta 42$ accumulation in APOE4-targeted replacement (TR) mice suggesting that lipidation of apoE4 is key to its pathophysiological properties [27].

In the brain, the major apoE receptors are the lowdensity lipoprotein receptor (LDLR) [28] and LDLRrelated protein 1 (LRP1) [29, 30]. In addition, heparan sulphate proteoglycan (HSPG) on the cell surface also mediates cellular uptake of apoE lipoprotein particles, either independently or in coordination with LRP1 [31]. Heparan sulphate proteoglycan is abundantly expressed on the cell surface and functions as a receptor that interacts with a variety of ligands through electrostatic interactions [32]. In conjunction with LRP1, HSPG plays an important role in neuronal cellular uptake of $A \beta$, which also possesses a heparin-binding region [25, 33]. HSPG controls the entry of a variety of molecules on the cell surface, including tau, $\alpha$-synuclein and soluble APP $[34,35]$.

In this study, we aimed to elucidate whether the previously reported apoE-mediated decrease in cellular $A \beta$ binding and uptake is orchestrated through competition between apoE and A $\beta$ for HSPG binding. We further aimed to clarify if such an interaction is apoE isoformdependent. For these purposes we used immortalized astrocyte-produced human apoE3 and apoE4 lipoprotein particles, Chinese hamster ovary $(\mathrm{CHO})$ cells, with or without HSPG, and primary cultured neurons. We show that apoE3 and apoE4 particles in a similar way irrespective of lipidation status compete with cellular $A \beta$ binding and uptake in a manner that depends on cell surface HSPG.

\section{Results}

Astrocyte-secreted apoE3 particles carry more lipids than apoE4 particles

Western blot of apoE3 and apoE4 after separation by nondenaturing gel revealed high molecular weight particles $(>232 \mathrm{kDa})$ in both the apoE3 and apoE4 preparations with a slightly higher presence of higher molecular weight particles $(>669 \mathrm{kDa})$ in the apoE3 preparation (Fig. 1a). Upon separation of apoE3 and apoE4 under reducing conditions, both apoE3 and apoE4 were detected at the expected molecular size of monomeric apoE $(\sim 37 \mathrm{kDa})$ (Fig. 1b). Employing a total cholesterol quantification assay, the total cholesterol levels in the apoE3 particle preparation was found to be $1.61 \pm 0.12 \mu \mathrm{g}$ cholesterol/ $\mu \mathrm{g}$ apoE, whereas the apoE4 particle preparation contained $0.53 \pm 0.13 \mu \mathrm{g}$ cholesterol $/ \mu \mathrm{g}$ apoE (Fig. 1c).

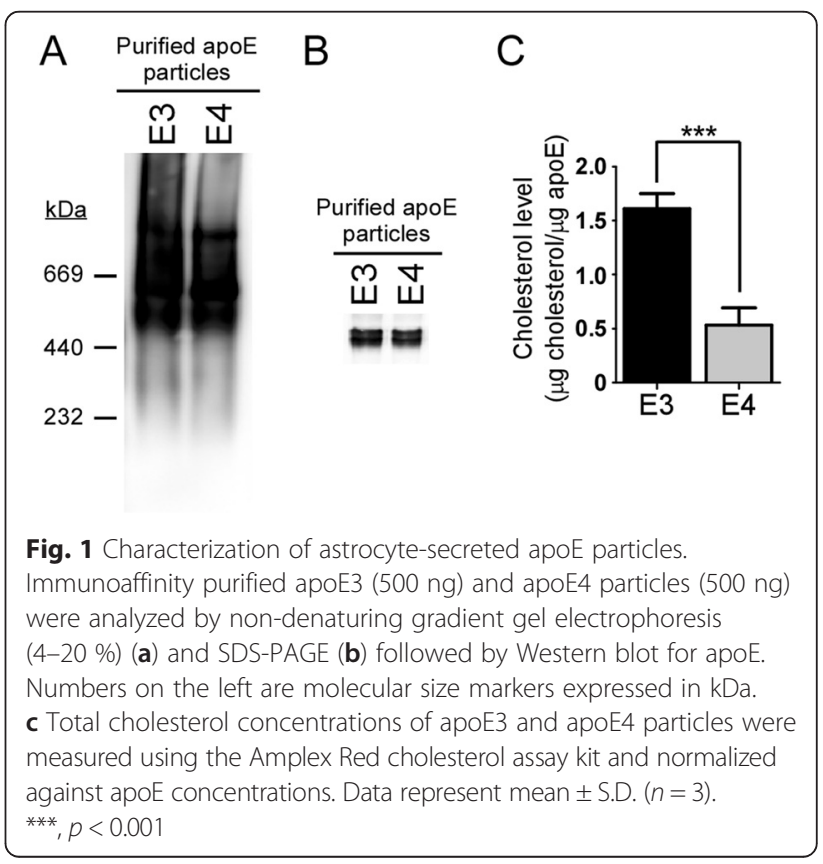


Similar results were obtained using apoE3 and apoE4 particles secreted by primary astrocytes from apoE-TR mice (Additional file 1: Figure S1). Together, these results indicate that apoE produced by astrocytes exists as lipoprotein particles with apoE3 particles carrying more cholesterol compared to apoE4 particles.

\section{ApoE binds to heparin and requires HSPG for cell internalization}

To determine whether immortalized astrocyte-produced apoE particles bind to heparin, we injected purified apoE3 and apoE4 particles into a Hitrap heparin HP column attached to FPLC and eluted apoE with a linear gradient of increasing concentrations of $\mathrm{NaCl}$. The concentration of apoE in each fraction was quantified by ELISA. ApoE3 particles and apoE4 particles bound to heparin column and were effectively eluted with $\mathrm{NaCl}$. The peaks of both apoE isoforms were detected after elution with a supraphysiological $\mathrm{NaCl}$ concentration of $0.45 \mathrm{M}$, which showed similar patterns with no obvious difference in the elution profiles between apoE3 and apoE4 particles (Fig. 2a). These results suggest that apoE
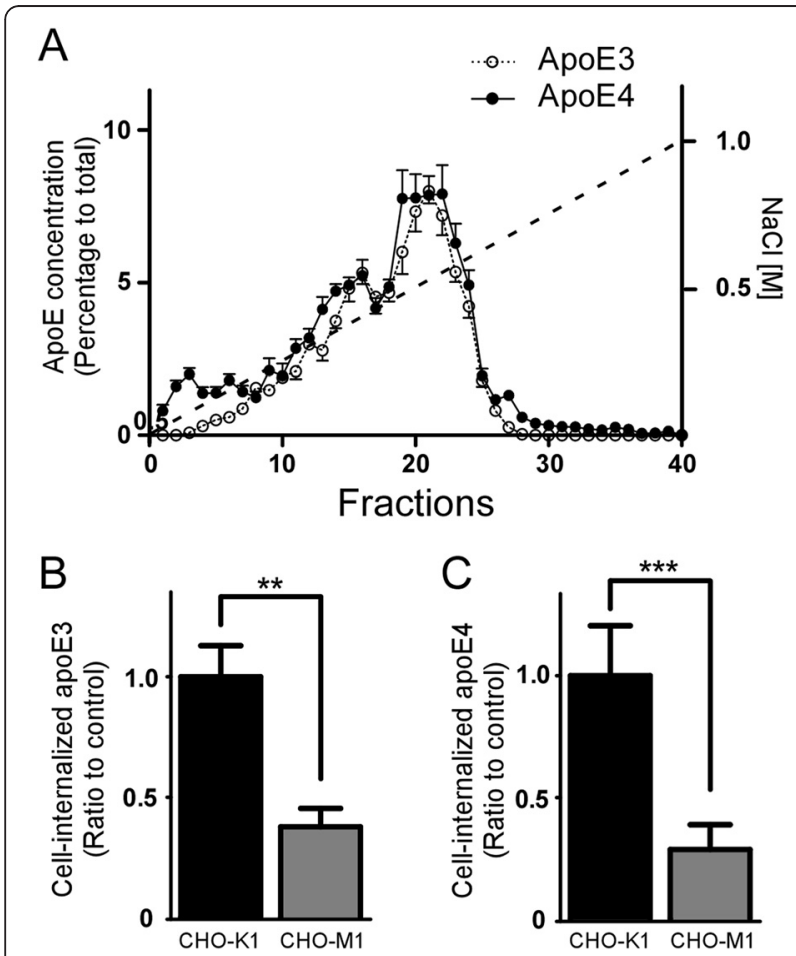

Fig. 2 ApoE particles bind to heparin and cell surface HSPG. ApoE3 particles $(3.4 \mu \mathrm{g})$ and apoE4 particles $(3.4 \mu \mathrm{g})$ were applied to HiTrap Heparin HP columns attached to a FPLC and eluted with a linear salt gradient (0-1.0 M NaCl). Concentrations of apoE in each fraction were determined by ELISA (a). An average of $n=3$ experiments are plotted in the graph. CHO-K1 or CHO-M1 cells were incubated with apoE3 (200 nM) (b) or apoE4 (200 nM) (c) for $18 \mathrm{~h}$ at $37^{\circ} \mathrm{C}$.

Internalization of apoE was analyzed by ELISA. Data represent mean \pm S.D. $(n=3) .{ }^{* *}, p<0.01 ;{ }^{* * *}, p<0.001$ particles, independent of isoform, strongly interact with heparin at $\mathrm{NaCl}$ concentrations $<0.45 \mathrm{M}$ and thus apoE likely binds to cell surface HSPG under physiological conditions. Furthermore, to determine the kinetics of apoE-heparin binding, their binding affinity was analyzed by dot blot. The dissociation constant $(\mathrm{Kd})$ value between apoE3 particles and heparin was calculated as $\sim 201 \mathrm{nM}$ (Additional file 2: Figure S2).

To further confirm the role of HSPG in apoE cellular uptake, we used wild-type CHO-K1 cells and CHO-M1 cells lacking $\mathrm{N}$-acetylglucosaminyltransferase/glucuronyltransferase, which is required for the biosynthesis of heparan sulphate [36]. When $\mathrm{CHO}-\mathrm{K} 1$ or $\mathrm{CHO}-\mathrm{M} 1$ cells were incubated with apoE3 or apoE4 particles (200 nM) for $18 \mathrm{~h}$, the amounts of cell-associated apoE were $62 \%$ (Fig. 2b) and $71 \%$ (Fig. 2c) lower in CHO-M1 cells than those of $\mathrm{CHO}-\mathrm{K} 1$ cells. These results indicate that HSPG is a major receptor facilitating the cellular uptake of astrocyte-secreted apoE particles in CHO cells.

\section{ApoE particles compete with $A \beta$ for internalization through HSPG}

To investigate effects of apoE on cellular $\mathrm{A} \beta$ uptake, $\mathrm{CHO}$ cells were incubated with $50 \mathrm{nM}$ of $\mathrm{A} \beta 40$ or $\mathrm{A} \beta 42$ in the presence or absence of apoE particles for $18 \mathrm{~h}$ at $37^{\circ} \mathrm{C}$. The amount of cell-associated $\mathrm{A} \beta$ was assessed by ELISA. We found that the amounts of $A \beta 40$ (Fig. 3a) and $A \beta 42$ (Fig. 3b) were significantly reduced by both apoE3 and apoE4 particles $(200 \mathrm{nM})$ in $\mathrm{CHO}-\mathrm{K} 1$ cells. The internalization of both $A \beta 42$ and $A \beta 40$ in $\mathrm{CHO}-\mathrm{M} 1$ cells was significantly lower than in $\mathrm{CHO}-\mathrm{K} 1$ cells, consistent with a role of cell surface HSPG in cellular A $\beta$ uptake [33]. More importantly, the effects of apoE particles on cellular $A \beta$ uptake were completely abolished in CHO-M1 cells. To further interrogate the effects of apoE particles on cellular $\mathrm{A} \beta$ uptake, we performed a competition assay using fixed concentration of A $\beta 42(50 \mathrm{nM})$ and increasing concentrations of apoE particles (0.2 nM to $200 \mathrm{nM})$ in CHO cells. Both apoE isoforms significantly suppressed A $\beta 42$ internalization in $\mathrm{CHO}-\mathrm{K} 1$ cells in a concentration-dependent manner (Fig. 4). These results indicate that apoE particles compete with $\mathrm{A} \beta$ for cellular uptake in a manner that depends on cell surface HSPG. We next investigated whether apoE affects A $\beta$ binding to cell surface HSPG. $\mathrm{CHO}-\mathrm{K} 1$ cells and CHO-M1 cells were incubated with A $342(50 \mathrm{nM})$ in the presence or absence of astrocytesecreted apoE (200 nM) at $4{ }^{\circ} \mathrm{C}$ for $3 \mathrm{~h}$. When the amount of cell-associated $\mathrm{A} \beta$ was analyzed by ELISA, approximately $1 \%$ of the added $A \beta$ was bound to the cells. We found that both apoE3 and apoE4 particles in a similar manner inhibited $\mathrm{A} \beta$ binding to the cell surface in $\mathrm{CHO}$ $\mathrm{K} 1$ cells. However, these effects were absent in CHO-M1 cells (Fig. 5), indicating that apoE particles reduce $A \beta$ binding to cell surface HSPG. 

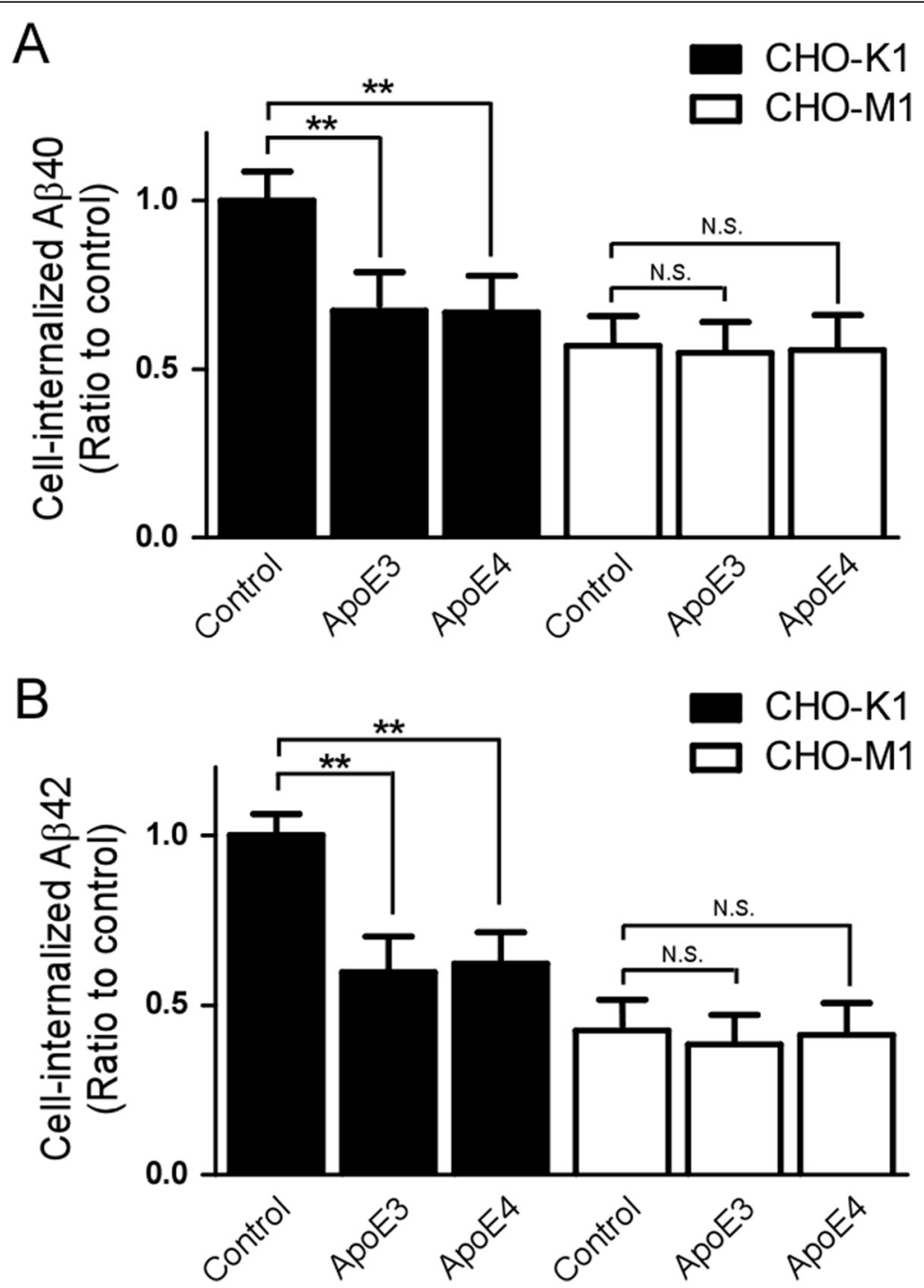

Fig. 3 ApoE particles inhibit A $\beta$ cellular uptake through HSPG in CHO cells. CHO-K1 (wild-type) cells or CHO-M1 (HS-deficient) cells were incubated with $50 \mathrm{nM} \mathrm{A \beta 40}(\mathbf{a})$ or $50 \mathrm{nM} \mathrm{A \beta 42}$ (b) in the presence or absence of apoE3 particle (200 nM) or apoE4 particle (200 nM) for $18 \mathrm{~h}$ at $37^{\circ} \mathrm{C}$. The amount of internalized A $\beta$ was quantified by ELISA. Data represent mean \pm S.D. $(n=3) .{ }^{*}, p<0.01$

ApoE particles inhibit HSPG-mediated cell-association of $A \beta$ in primary neurons

To determine whether the observed effects of apoE particles on $A \beta$ uptake are also relevant in neurons, we analyzed the effects of apoE3 particles on $A \beta$ uptake in the presence or absence of heparin in mouse primary cortical neurons, as there is no detectable difference between apoE3 and apoE4 particles on $A \beta$ uptake in $\mathrm{CHO}$-cells. Neurons were incubated with $\mathrm{A} \beta 42$ in the presence or absence of apoE3 particles with or without heparin to antagonize HSPG binding for $6 \mathrm{~h}$ at $37{ }^{\circ} \mathrm{C}$ and analyzed by confocal microscopy (Fig. 6a). When neuronal cell bodies were observed by confocal microscopy, internalized $\mathrm{A} \beta$ was mainly co-localized with a lysosomal marker, LysoTracker. In the presence of apoE3 particles or heparin, A $\beta 42$ internalization was reduced compared to the controls (Fig. 5). The effect of apoE3 particles on $A \beta$ uptake was not observed when heparin was co-incubated (Fig. 5). Consistent with the results from confocal microscopy, FACS revealed that apoE3 particles and heparin significantly suppressed cellassociated A $\beta 42$ levels. More importantly, the effects of apoE3 particles on A $\beta 42$ uptake were eliminated by heparin (Fig. 6b). Together, these results indicate that apoE particles inhibit neuronal A 342 uptake though their binding to cell surface HSPG.

\section{Discussion}

Interaction of $A \beta$ with the neuronal cell surface significantly affects synaptic functions and may induce neuronal toxicity in AD pathogenesis $[37,38]$. The binding of $\mathrm{A} \beta$ to synapses alters the distribution and/or activities of 


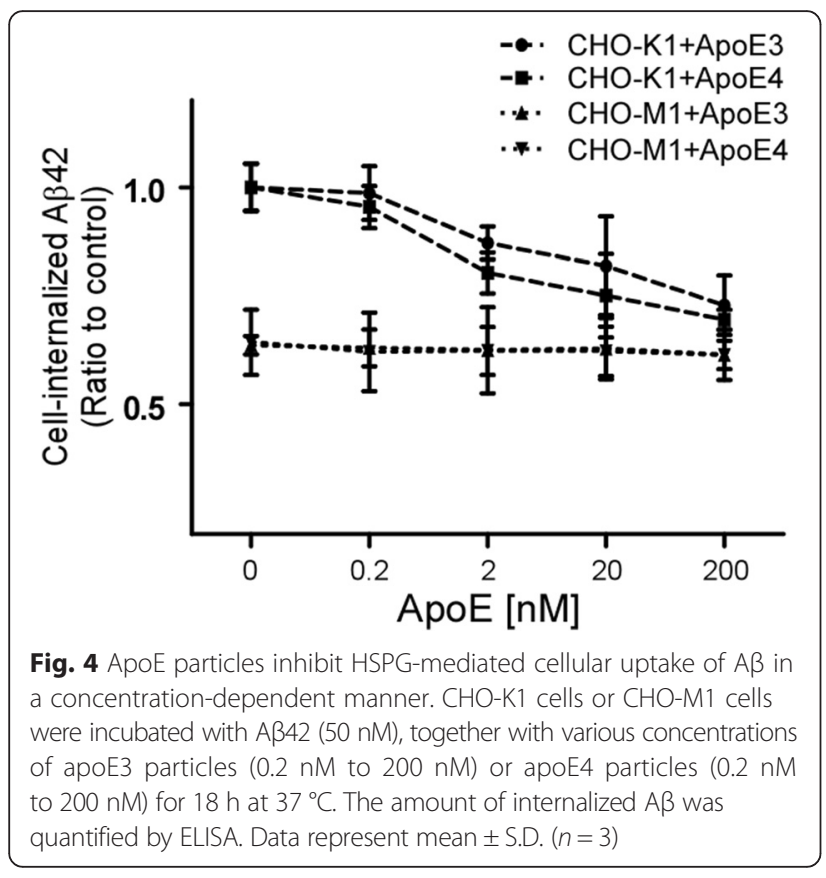

signaling receptors including $\mathrm{N}$-methyl $\mathrm{D}$-aspartate (NMDA) receptors [39] and metabotropic glutamate receptors (mGluR5) [40], leading to synapse deterioration and impairment of learning and memory. Oligomeric $A \beta$ also binds to prion protein $(\mathrm{PrPc})$, resulting in significant synaptic dysfunction [41]. Cell-surface HPSG may be heavily involved in these processes as HSPG mediates binding and uptake of aggregated $A \beta$ and monomeric $A \beta$ on the cell surface $[33,42,43]$. HSPGs are composed of a core protein, several heparan sulphate [44] glycosaminoglycan [44, 45] chains, and uronic acid [46]. Heparan sulphate chains, which have a high negative charge,

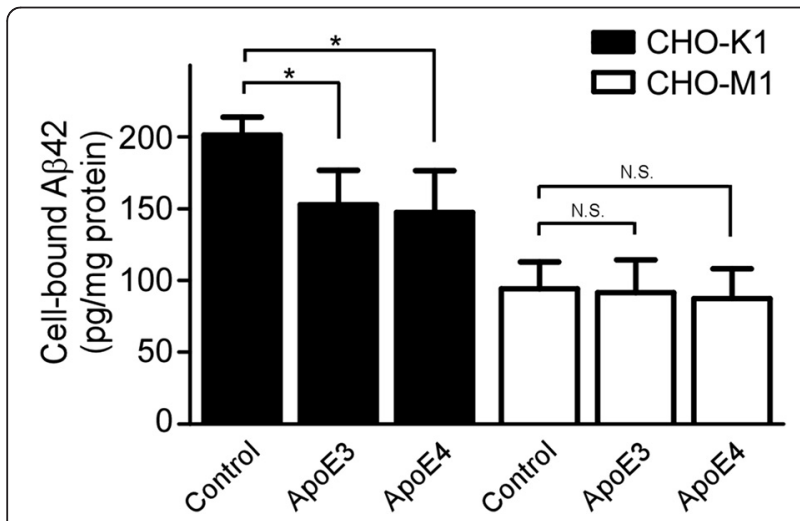

Fig. 5 ApoE particles suppress A $\beta$ binding to HSPG on the cell surface. CHO-K1 or CHO-M1 cells were incubated with A $342(50 \mathrm{nM})$ with or without apoE3 particles (200 nM) or apoE4 particles (200 nM) for $3 \mathrm{~h}$ at $4{ }^{\circ} \mathrm{C}$. Cell-bound $\mathrm{A} \beta 42$ was quantified by ELISA. Data represent mean \pm S.D. $(n=3) .{ }^{*}, p<0.05$ presumably interact with the binding sites in the protein with positive charges [46].

Receptor-mediated cellular uptake and subsequent lysosomal degradation is an important pathway for $A \beta$ clearance [47]. For example, LRP1 regulates cellular A $\beta$ uptake in neurons [48] and vascular smooth muscle cells [49], and the disturbances of this pathway exacerbates amyloid pathology in amyloid mouse models. ApoE is also likely to interact directly with LRP1 and competes with $A \beta$ in the cellular clearance process at their physiological concentrations [26]. These observations support previous findings that apoE may have a suppressive effect from the perspective of cellular $A \beta$ elimination by inhibiting cellular $A \beta$ clearance pathways in both rodent astrocytes [26] and primary human astrocytes and microglia $[19,20,26]$. Interestingly, the clearance of soluble $A \beta$ in brain interstitial fluid is significantly accelerated in Apoe-KO mice [16] and decreased apoE expression under haploinsufficiency also results in less $\mathrm{A} \beta$ deposition in amyloid mouse models expressing human apoE isoforms [50, 51]. Further, immunotherapy for apoE also reduces $A \beta$ accumulation in rodent models [52, 53].

Although binding of A $\beta$ to cell surface HSPG can lead to its subsequent trafficking to lysosomes for degradation, there is also strong evidence that such interaction can be harmful by promoting $\mathrm{A} \beta$ aggregation and oligomer formation [54, 55]. Several studies have shown that soluble $A \beta$ oligomers injure synapses resulting in impairment of cognitive function through direct binding, and the levels of $A \beta$ in the brain of $A D$ patients are positively associated with synaptic protein and cognitive decline $[44,56,57]$. In these cases, inhibition of $A \beta$ binding to cell surface HSPG by apoE particles can be beneficial by reducing the formation of harmful $A \beta$ oligomers. Mounting evidence has shown that the APOE $\varepsilon 4$ allele dramatically increases the risk for $\mathrm{AD}$, where apoE4 contributes to $\mathrm{AD}$ pathogenesis by both loss-of-function in neuroprotection and gain-of-function in neurotoxicity compared to apoE3 $[47,58]$. Although isoform-dependent effects were not detected in the current study, apoE particles blocked the internalization of $A \beta$ in a concentrationdependent manner. As apoE indeed could act as an inducer of $\mathrm{A} \beta$ fibril formation with apoE4 exhibiting the strongest fibril catalytic activity [59], apoE isoforms may differently modulate $A \beta$ aggregation status which influences $A \beta$ proteolytic degradation, rather than affecting cellular $A \beta$ uptake. In addition, we found that our purified apoE4 particles contained less cholesterol than apoE3 particles, which is consistent with earlier studies proposing apoE4 as a less efficient lipid-carrier [27, 60]. Thus, the less lipidation status of apoE4 may also be involved in the exacerbated $A \beta$ plaque accumulation through apoE4induced $A \beta$ aggregation. 

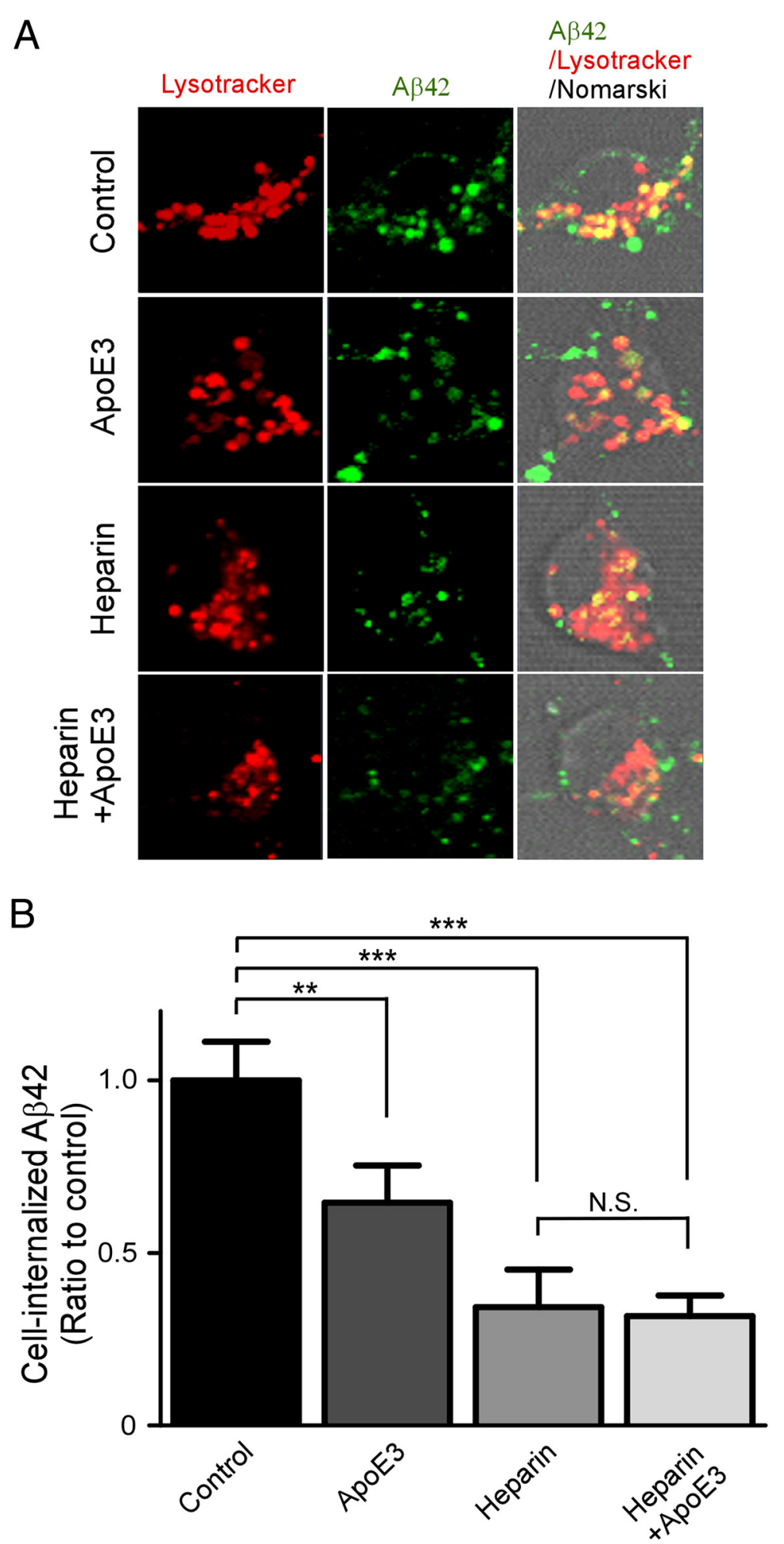

Fig. 6 ApoE particles decrease HSPG-mediated cellular uptake of A $\beta$ in primary neurons. a Mouse primary cortical neurons were incubated with FAM-AB42 (500 nM) with or without apoE3 particles (200 nM) in the presence or absence of heparin $(15 \mathrm{U} / \mathrm{ml})$ for $6 \mathrm{~h}$ at $37^{\circ} \mathrm{C}$ and analyzed by confocal microscopy. Left, middle, and right columns indicate Lysotracker, FAM-A 342 , and merged images, respectively. $\mathbf{b}$ Internalization of A $\beta$ was quantified by FACS after incubation with FAM-Aß42 (500 nM) for 6 h. Data represent mean \pm S.D. $(n=3)$. N.S., not significant; ${ }^{* *}, p<0.01$; ***,,$p<0.001$ 
Furthermore, we found that apoE particles compete with A $\beta$ for HSPG binding and subsequent cellular uptake in $\mathrm{CHO}$ cells and neurons. By applying apoE3 and apoE4 to a heparin HiTrap column, we found that both apoE3 and apoE4 bound tightly to heparin at physiological $\mathrm{NaCl}$ concentrations $(<0.45 \mathrm{M})$. Consistent with our results, surface plasmon resonance failed to detect significant differences between apoE isoforms for their bindings to heparin [61]. Another study has also demonstrated that there are no significant differences in rate and equilibrium constants of binding among the lipidated apoE isoforms to heparin [24]. Since apoE has heparin binding sites in both the $\mathrm{N}$-terminal and $\mathrm{C}$ terminal domains with binding motifs identical between apoE3 and apoE4 [23, 24], it is not surprising that these apoE isoforms have similar binding affinities to heparin. Using dot blot, we also investigated whether the astrocytesecreted apoE3-heparin affinity constant was similar to apoE-heparin binding constants previously reported for recombinant and plasma-derived apoE [24, 61, 62]. We estimated the $\mathrm{Kd}$ to be $201 \mathrm{nM}$ which resembles the apoE3-heparin constant reported by Libeu and colleagues who found a $\mathrm{Kd}$ of $320 \mathrm{nM}$ as determined by surface plasmon resonance [62], however recombinant apoE was reported to bind heparin with higher affinity than that we determined in the current study [61].

Previously $\mathrm{A} \beta$ was proposed to bind and form stable complexes with apoE $[9,63,64]$; however, under physiological conditions only a small portion of $A \beta$, estimated at less than $5 \%$ of total $A \beta$, was found to interact with apoE particles [26]. It was proposed that despite minimal interaction between apoE and $A \beta$, these two players in solution compete for cellular uptake by astrocytes. Consistent with that report, we also found limited molecular interaction between $\mathrm{A} \beta(50 \mathrm{nM})$ and apoE $(200 \mathrm{nM})$ as assessed using SEC under which $A \beta$ and apoE eluted in separate fractions when quantified by ELISA (Additional file 3: Figure S3). These seemingly conflicting results in regard to apoE-A $\beta$ binding may be due to various studies employing different conditions, such as the concentrations of apoE and $A \beta$, their aggregation state and apoE lipidation state. It has been shown that CSF concentrations of apoE range between 2 and $7 \mu \mathrm{g} / \mathrm{ml}(\sim 200 \mathrm{nM})[65,66]$, whereas the interstitial fluid concentrations of $A \beta$ were found to be up to $\sim 2000 \mathrm{pg} / \mathrm{ml}(\sim 0.5 \mathrm{nM})$ [67]. Although the focal concentration of apoE and $A \beta$ remain unclear in particular in the synaptic region, our results suggest that apoE does not or only minimally interact with $A \beta$ under our experimental conditions.

In humans, higher levels of apoE tissue concentrations were previously shown to correlate with lower $A \beta$ burden in human brain homogenates [68] and increased CSF apoE levels were associated with higher CSF A $\beta 42$ levels indicative of lower $A \beta$ plaque burden [66]. Indeed, increasing apoE by retinoid $\mathrm{X}$ receptor (RXR) and liver $\mathrm{X}$ receptor (LXR) agonist has been shown to decrease A $\beta$ deposition in amyloid mouse models [69, 70]. We also recently reported that retinoic acid (RA) isomers including all-trans-RA, 9-cis-RA, and 13-cis-RA can increase the astrocyte-secreted apoE level through the $\mathrm{RXR} /$ retinoic acid receptor pathway and simultaneously decreased the amount of cell-associated $A \beta$ in immortalized astrocytes [71]. Thus, the regulation of brain apoE levels through these receptors likely contributes to $A \beta$ metabolism in $\mathrm{AD}$ pathogenesis.

\section{Conclusions}

Overall, our findings support previous reports showing an inhibitory effect of apoE on cellular $A \beta$ uptake and further extend those results by demonstrating that both apoE3 and apoE4 particles similarly reduce cellular $A \beta$ uptake through interactions with cell surface HSPG in $\mathrm{CHO}$ cells and neurons. In addition, apoE lipidation status may not contribute to its inhibitory effect on cellular $\mathrm{A} \beta$ binding and uptake. Together these findings propose potent effects of apoE on $A \beta$ clearance possibly by inhibiting cellular uptake which may promote the keeping of $A \beta$ in the extracellular space readily available for proteolytic degradation. The interaction between apoE and HSPG may be critical to the development of AD pathology by modulating the extra- versus intracellular pools of $A \beta$ with down-stream effects on several AD-related pathways. Our findings propose that modulating the interaction between apoE, A $\beta$ and HSPG may be an attractive target to be explored for AD therapy.

\section{Methods \\ Reagents}

5(6)-Carboxyfluorescein (FAM)-A $\beta 42$, synthetic $A \beta 40$, and synthetic $A \beta 42$ were purchased from AnaSpec (Fremont, CA). LysoTracker Red was purchased from Invitrogen. Heparin was purchased from Baxter Healthcare Corp. (Round Lake, IL).

\section{Preparation of apoE particles}

Immortalized apoE astrocyte cell lines producing human apoE3 or apoE4, kind gifts from Dr. David Holtzman [72], were cultured in DMEM/F12 (Invitrogen) with $20 \%$ fetal bovine serum (Gibco), $1 \mathrm{mM}$ sodium pyruvate, $1 \mathrm{x}$ non-essential amino acids, $2 \mathrm{mM} \mathrm{L}$-glutamine, and $1 \%$ penicillin/streptomycin (Invitrogen). This cell line was generated from primary astrocytes derived from human $A P O E$-TR mice, in which human $A P O E$ gene is knocked into the mouse Apoe locus. Cells were cultured at $37{ }^{\circ} \mathrm{C}$ in humidified air containing $5 \% \mathrm{CO}_{2}$. For purification of apoE lipoprotein particles, WUE-4, a mouse monoclonal antibody to human apoE [73], was coupled to $\mathrm{CNBr}$-activated Sepharose 4B (GE Healthcare) and 
immunoaffinity columns were prepared as described [74]. ApoE lipoprotein particles were then purified from conditioned serum-free media of immortalized astrocytes by using apoE antibody columns as described [72].

\section{Western blot}

Samples were separated by electrophoresis on either a nondenaturing 4-20\% polyacrylamide gradient gel or on a $10 \%$ sodium dodecyl sulfate (SDS)-polyacrylamide gel (PAGE) as described [73], transferred to nitrocellulose membrane, and probed with a monoclonal antibody to human apoE (WUE-4) followed by an HRP-conjugated secondary antibody. The immunoreactive proteins were detected using enhanced chemiluminescence (ECL, Thermo) with images obtained with the Fujifilm ${ }^{\circ}$ LAS-4000 gel imager.

\section{Cholesterol assay}

Total cholesterol contents of the apoE3 and apoE4 particles were quantified with the Amplex Red cholesterol assay kit (Invitrogen) according to the manufacturer's protocol.

\section{Heparin-apoE interaction by affinity chromatography}

Binding of apoE lipoprotein particles to heparin was assessed using a heparin column as described previously [75]. In brief, a $1 \mathrm{ml}$ HiTrap heparin HP column (GE Healthcare) was attached to a fast protein liquid chromatography (FPLC) (GE Healthcare) and run at a flow rate of $1 \mathrm{ml} / \mathrm{min}$. $3.4 \mu \mathrm{g}$ of apoE3 or apoE4 were loaded, and the column was washed with $20 \mathrm{mM}$ Tris $-\mathrm{HCl}$, $\mathrm{pH} 7.4$ for 10 column volumes. Bound apoE was eluted in the same buffer using a linear gradient of $0-1.0 \mathrm{M}$ $\mathrm{NaCl}$.

\section{Heparin-apoE interaction by dot-blot analysis}

WUE-4 (mouse monoclonal anti-apoE antibody), normal mouse IgG (Invitrogen), and heparin (Sigma-Aldrich) were spotted onto a nitrocellulose membrane (Bio-Rad) using dot blot manifold apparatus (GE Healthcare). Membrane strips were then incubated with increasing concentrations of astrocyte-produced apoE3 particles overnight at $4{ }^{\circ} \mathrm{C}$. ApoE bound to the membrane was detected with biotin-conjugated goat anti-apoE (Meridian Life Science) and Streptavidin secondary antibodies. Blots were imaged and quantified using Odyssey Infrared Imaging System (LI-COR Biosciences). For determination of binding affinity, the integrated infrared signal (K Count) of each dot was analyzed using Prism (Graphpad).

\section{Cell culture}

Wild-type (K1) and HSPG-deficient (M1) Chinese hamster ovary $(\mathrm{CHO})$ cells were grown in Ham's F-12 medium containing $10 \%$ fetal bovine serum (Gibco) and $1 \%$ penicillin/streptomycin (Invitrogen). Primary cortical neurons were isolated from 17 days old embryos of wild-type C57BL/6 mice and grown in Neurobasal medium (Invitrogen) supplemented with $0.5 \mathrm{mM}$ GlutaMax (Invitrogen), and B27 (Invitrogen) [33, 76].

\section{Primary astrocyte cultures}

Primary astrocytes were prepared from new-born pups (P1-P2) with apoE3-TR and apoE4-TR background. In brief, the brain was removed from the skull and the meninges were discarded. Subsequently, the cortices were minced and incubated with $0.05 \%$ trypsin at $37{ }^{\circ} \mathrm{C}$ for $15 \mathrm{~min}$. Enzyme-digested dissociated cells were triturated with astrocyte growth medium and centrifuged at $300 \times \mathrm{g}$ for $5 \mathrm{~min}$. The cell pellet was resuspended in fresh medium, passed through a 70- $\mu$ m nylon mesh, and centrifuged at $300 \times \mathrm{g}$ for $5 \mathrm{~min}$. The cells were plated on poly-D-lysine-coated 75-flask in the media, which were changed every three days. Cells were grown until confluence. Medium was collected and purified using the same method described above.

\section{Membrane protein extraction}

Membrane protein was extracted according to the protocol of Thermo Scientific Mem-PER Plus Membrane Protein Extraction Kit. Briefly, $5 \times 10^{6}$ cells were suspended in the growth media by scraping the cells off the surface of the plate with a cell scraper. After centrifugation at $300 \times \mathrm{g}$ for $5 \mathrm{~min}$, cell pellet was resuspended in $1.5 \mathrm{ml}$ of Cell Wash Solution, and centrifuged at $300 \times \mathrm{g}$ for $5 \mathrm{~min}$. The pellet was resuspended in $0.75 \mathrm{ml}$ of Permeabilization Buffer, and incubated for $10 \mathrm{~min}$ at $4{ }^{\circ} \mathrm{C}$ with constant mixing. After centrifugation for $15 \mathrm{~min}$ at $16,000 \times \mathrm{g}$, the pellet was dissolved in $0.5 \mathrm{ml}$ of Solubilization Buffer and incubated at $4{ }^{\circ} \mathrm{C}$ for 30 min with constant mixing. Supernatant containing solubilized membrane and membrane-associated proteins was collected after centrifugation at $16,000 \times \mathrm{g}$ for 15 min at $4{ }^{\circ} \mathrm{C}$, and used for Western Blot. Protein was loaded after normalized with the level of $\mathrm{Na}^{+}-\mathrm{K}^{+}$-ATPase. Level of LRP1 was analyzed in the membrane fractions isolated from $\mathrm{CHO}-\mathrm{K} 1$ and $\mathrm{CHO}-\mathrm{M} 1$ cells (Additional file 4: Figure S4).

\section{Detection of cell-associated $A \beta$ and apoE by ELISA}

Cells were incubated with $\mathrm{A} \beta 42(50 \mathrm{nM})$ or $\mathrm{A} \beta 40(50 \mathrm{nM})$ in the presence of various concentrations of apoE3 or apoE4 (0.2-200 nM) in serum free medium for $18 \mathrm{~h}$ at $37^{\circ} \mathrm{C}$, and harvested by incubating with trypsin for 5 min at $37{ }^{\circ} \mathrm{C}$. After washing two times with PBS, cells were dissolved in $5 \mathrm{M}$ guanidine in $50 \mathrm{mM}$ Tris- $\mathrm{HCl}$ ( $\mathrm{pH}$ 8.0). To quantify cellular internalization of human $\mathrm{A} \beta 42, \mathrm{~A} \beta 42$ was captured with mAb 2.1.3 antibody followed by detection with HRP-conjugated Ab5 antibody [76]. To determine human apoE concentrations, apoE was 
captured using apoE monoclonal antibody WUE-4 [73], detected with biotin-conjugated goat anti-apoE antibody (Meridian Life Science) and poly-HRP-conjugated streptavidin (Fitzgerald) essentially as previously described [71]. To assess cell-bound $A \beta$, cells were incubated with $A \beta 42$ $(50 \mathrm{nM})$ with or without apoE3 particles $(200 \mathrm{nM})$, or apoE4 particles $(200 \mathrm{nM})$, for $3 \mathrm{~h}$ at $4{ }^{\circ} \mathrm{C}$ in PBS with $1.5 \%$ FBS after suspension by Cell Dissociation Solution. After washing three times with PBS, cells were dissolved in $5 \mathrm{M}$ guanidine in $50 \mathrm{mM}$ Tris- $\mathrm{HCl}(\mathrm{pH}$ 8.0) The $\mathrm{A} \beta$ concentration in the cell lysate was quantified by ELISA and normalized by the protein concentration of the cell lysate [33].

\section{Size-exclusion chromatography (SEC) to determine apoE- $A \beta$ interaction}

Immunopurified apoE3 (200 $\mathrm{nM})$ was incubated in serum-free DMEM-F12 medium containing $A \beta$ (50 $\mathrm{nM}$ ) for $3 \mathrm{~h}$. The sample was loaded on SEC by fast protein liquid chromatography (FPLC) using tandem Superose-6, 10/300 GL columns (GE Healthcare) in phosphate buffer containing $50 \mathrm{mM}$ sodium phosphate (pH 7.4), $150 \mathrm{mM} \mathrm{NaCl}, 1 \mathrm{mM}$ EDTA, and $0.02 \%$ sodium azide [71]. To determine a potential association between apoE and $A \beta$, the concentrations of both apoE and $A \beta$ in each fraction were determined by ELISA as described above.

\section{Confocal imaging of neuronal $A \beta$ uptake}

Mouse primary cortical neurons were cultured on eightwell chambered cover glasses (Nalge Nunc International, Rochester, NY). After incubation with FAM-A $\beta 42$ (500 $\mathrm{nM})$ at $37{ }^{\circ} \mathrm{C}$ for $6 \mathrm{~h}$, together with or without apoE3 particles $(200 \mathrm{nM})$ in the presence or absence of heparin $(15 \mathrm{U} / \mathrm{ml})$, fluorescence associated with $A \beta$ was observed by confocal laser-scanning fluorescence microscopy (model LSM510 invert; Carl Zeiss, Jena, Germany). LysoTracker (50 nM; Invitrogen) was added to determine lysosome-A $\beta$ colocalization $30 \mathrm{~min}$ before confocal imaging.

\section{Fluorescence-activated cell sorter-based $A \beta$ internalization assays}

Mouse primary cortical neurons were incubated with FAM-A 342 (500 nM), together with vehicle or apoE3 (200 nM) in the presence or absence of heparin at $37{ }^{\circ} \mathrm{C}$ for $6 \mathrm{~h}$. Cell-surface $\mathrm{A} \beta$ was removed using $0.25 \%$ trypsin/EDTA (Invitrogen), and cell-associated A $\beta$ was analyzed for fluorescence on a BD FACSCalibur (BD Biosciences). Control cells without any exposure to fluorescence were used to assess background fluorescence [33].

\section{Statistical analysis}

All quantified data represent an average of triplicate samples and were analyzed by either $t$-test or one-way ANOVA with a Tukey's posttest. Error bars represent standard deviation and $p<0.05$ was considered significant.

\section{Additional files}

\begin{abstract}
Additional file 1: Figure S1. ApoE particles secreted by primary astrocytes from apoE-TR mice. (A) ApoE3 and apoE4 particles were isolated from condition medium of primary astrocytes from apoE3-TR and apoE4-TR mice using immunoaffinity column. The purified apoE3 $(500 \mathrm{ng})$ and apoE4 particles $(500 \mathrm{ng})$ were analyzed by non-denaturing gradient gel electrophoresis (4-20\%) and SDS-PAGE, followed by Western blot for apoE. (B) Total cholesterol concentrations of the apoE3 and apoE4 particles were measured using the Amplex Red cholesterol assay kit and normalized against apoE concentrations. Data represent mean \pm S.D. $(n=3)$. $* *, p<0.001$. (TIF $213 \mathrm{~kb}$ )
\end{abstract}

Additional file 2: Figure S2. Binding affinity of heparin-apoE3 interaction. (A) Representative dot blot of heparin and apoE3 particles. Heparin was spotted onto nitrocellulose membrane along with mouse monoclonal anti-apoE antibody, WUE4, as a positive control and normal mouse $\lg G$ as a background. Membrane strips were incubated with increasing concentrations of apoE3 particles from immortalized astrocytes. Membrane-bound apoE was then visualized by biotin-conjugate anti-apoE antibody and infrared streptavidin secondary antibody. (B) Integrated infrared signal intensities from each dot were obtained and the average intensities from three independent experiments were plotted to acquire binding affinity curve and the dissociation constant (Kd). (TIF $2432 \mathrm{~kb}$ )

Additional file 3: Figure S3. ApoE particles are minimally associated with $A B$. AB was incubated without (A) or with apoE3 particles (B). Samples were applied to SEC with tandem Superose-6 columns. Concentrations of apoE and $A \beta$ in each fraction were analyzed by ELISA. Graphs are averaged from separate experiments $(n=3)$. (TIF $4171 \mathrm{~kb}$ )

Additional file 4: Figure S4. Similar LRP1 levels in the membrane fractions of $\mathrm{CHO}-\mathrm{K} 1$ cells and $\mathrm{CHO}-\mathrm{M} 1$ cells. Membrane fractions isolated from $\mathrm{CHO}-\mathrm{K} 1$ and $\mathrm{CHO}-\mathrm{M} 1$ cells were subjected to Western blot for LRP1 and Na-K-ATPase (A). The levels of LRP1 were normalized against those of $\mathrm{Na}^{+}-\mathrm{K}^{+}$-ATPase and plotted in (B). Data represent mean \pm S.D. $(n=3)$. N.S., not significant. (TIF $63 \mathrm{~kb})$

\section{Abbreviations}

$A \beta$ : amyloid- $\beta$; AD: Alzheimer's disease; ApoE: apolipoprotein E; HSPG: heparan sulphate proteoglycan; apoE-TR mice: apoE targetedreplacement mice; CHO: Chinese hamster ovary; LRP1: Iow-density lipoprotein receptor-related protein 1; LDLR: low-density lipoprotein receptor; APP: amyloid precursor protein; HDL: high density lipoprotein; NMDA: $\mathrm{N}$-methyl d-aspartate; mGluR5: metabotropic glutamate receptors; PrPc: prion protein; CSF: cerebrospinal fluid; RXR: retinoid $X$ receptor; $L X R$ : liver $X$ receptor; RA: retinoic acid.

\section{Competing interests}

The authors declare that they have no competing interests.

\section{Authors' contributions}

YF and JZ performed most experiments, collected and analyzed data, and wrote the manuscript. YA performed biochemical experiments. HMN and $\mathrm{CCL}$ contributed to cell culture. $\mathrm{HZ}$ and MS participated in the design of the study. Manuscript was written by YF and JZ, and critically reviewed by YA, HMN, CCL, HZ, MS, TK and GB. All authors read and approved the final manuscript.

\section{Acknowledgment}

This study was supported by NIH grants P01NS074969, R01AG027924, R01AG035355, and P01AG030128 (to G.B.), a grant from the Alzheimer's Association (G.B.) and Alzheimer's Association NIRG and Mayo Clinic CRM Career Development Award (to T.K.). NSFC grants (81500917) and science fund from 
HMU (HYDSYJQ201501) (to Y.F.). We would like to thank Dr. David Holtzman for immortalized apoE3 and apoE4 astrocytes, Dr. John Fryer for his assistance with data analysis and Caroline Stetler for careful reading of this manuscript.

\section{Author details Harbin Medical University, Harbin, Heilongjiang, China. \\ Received: 6 November 2015 Accepted: 19 April 2016 Published online: 05 May 2016}

'Department of Neuroscience, Mayo Clinic, Jacksonville, FL, USA. ${ }^{2}$ Fujian Provincial Key Laboratory of Neurodegenerative Disease and Aging Research, Institute of Neuroscience, College of Medicine, Xiamen University, Xiamen, Fujian, China. ${ }^{3}$ Department of Neurology, The Fourth Affiliated Hospital,

\section{References}

1. Blennow K, de Leon MJ, Zetterberg H. Alzheimer's disease. Lancet. 2006:368:387-403.

2. Hardy J, Selkoe DJ. The amyloid hypothesis of Alzheimer's disease: progress and problems on the road to therapeutics. Science. 2002;297:353-6.

3. Selkoe DJ. Alzheimer's disease: genes, proteins, and therapy. Physiol Rev. 2001;81:741-66.

4. Selkoe DJ. Deciphering the genesis and fate of amyloid beta-protein yields novel therapies for Alzheimer disease. J Clin Invest. 2002;110:1375-81.

5. Thies W, Bleiler L. Alzheimer's disease facts and figures. Alzheimers Dement. 2013;2013(9):208-45.

6. Tai LM, Mehra S, Shete V, Estus S, Rebeck GW, Bu G, Ladu MJ. Soluble apoE/ Abeta complex: mechanism and therapeutic target for APOE4-induced AD risk. Mol Neurodegener. 2014;9:2.

7. Mohamed A, Posse de Chaves E. Abeta internalization by neurons and glia. Int J Alzheimers Dis. 2011;2011:127984.

8. Corder EH, Saunders AM, Strittmatter WJ, Schmechel DE, Gaskell PC, Small GW, Roses AD, Haines JL, Pericak-Vance MA. Gene dose of apolipoprotein E type 4 allele and the risk of Alzheimer's disease in late onset families. Science. 1993;261:921-3.

9. Strittmatter WJ, Weisgraber KH, Huang DY, Dong LM, Salvesen GS, Pericak-Vance M, Schmechel D, Saunders AM, Goldgaber D, Roses AD. Binding of human apolipoprotein E to synthetic amyloid beta peptide: isoform-specific effects and implications for late-onset Alzheimer disease. Proc Natl Acad Sci U S A. 1993;90:8098-102.

10. Farrer LA, Cupples LA, Haines JL, Hyman B, Kukull WA, Mayeux R, Myers RH, Pericak-Vance MA, Risch N, van Duijn CM. Effects of age, sex, and ethnicity on the association between apolipoprotein E genotype and Alzheimer disease. A meta-analysis. APOE and Alzheimer Disease Meta Analysis Consortium. JAMA. 1997;278:1349-56.

11. Hu J, Liu CC, Chen XF, Zhang YW, Xu H, Bu G. Opposing effects of viral mediated brain expression of apolipoprotein E2 (apoE2) and apoE4 on apoE lipidation and Abeta metabolism in apoE4-targeted replacement mice. Mol Neurodegener. 2015;10:6

12. Kok E, Haikonen S, Luoto T, Huhtala H, Goebeler S, Haapasalo H, Karhunen PJ. Apolipoprotein E-dependent accumulation of Alzheimer disease-related lesions begins in middle age. Ann Neurol. 2009;65:650-7.

13. Liu DS, Pan XD, Zhang J, Shen H, Collins NC, Cole AM, Koster KP, Ben Aissa M, Dai XM, Zhou M, et al. APOE4 enhances age-dependent decline in cognitive function by down-regulating an NMDA receptor pathway in EFAD-Tg mice. Mol Neurodegener. 2015;10:7

14. Morris JC, Roe CM, Xiong C, Fagan AM, Goate AM, Holtzman DM, Mintun MA. APOE predicts amyloid-beta but not tau Alzheimer pathology in cognitively normal aging. Ann Neurol. 2010;67:122-31.

15. Mahley RW, Rall SC Jr. Apolipoprotein E: far more than a lipid transport protein. Annu Rev Genomics Hum Genet. 2000;1:507-37.

16. DeMattos RB, Cirrito JR, Parsadanian M, May PC, O'Dell MA, Taylor JW, Harmony JA, Aronow BJ, Bales KR, Paul SM, Holtzman DM. ApoE and clusterin cooperatively suppress Abeta levels and deposition: evidence that ApoE regulates extracellular Abeta metabolism in vivo. Neuron. 2004:41:193-202

17. Kanekiyo T, Xu H, Bu G. ApoE and Abeta in Alzheimer's disease: accidental encounters or partners? Neuron. 2014;81:740-54.

18. Bruinsma IB, Wilhelmus MM, Kox M, Veerhuis $R$, de Waal RM, Verbeek MM Apolipoprotein E protects cultured pericytes and astrocytes from D-Abeta(1-40)-mediated cell death. Brain Res. 2010;1315:169-80.
19. Nielsen HM, Mulder SD, Belien JA, Musters RJ, Eikelenboom P, Veerhuis R. Astrocytic A beta 1-42 uptake is determined by A beta-aggregation state and the presence of amyloid-associated proteins. Glia. 2010;58:1235-46

20. Mulder SD, Nielsen HM, Blankenstein MA, Eikelenboom P, Veerhuis R. Apolipoproteins $E$ and $J$ interfere with amyloid-beta uptake by primary human astrocytes and microglia in vitro. Glia. 2014;62:493-503.

21. Mulder SD, Veerhuis R, Blankenstein MA, Nielsen HM. The effect of amyloid associated proteins on the expression of genes involved in amyloid-beta clearance by adult human astrocytes. Exp Neurol. 2012;233:373-9.

22. Winkler K, Scharnagl H, Tisljar U, Hoschutzky H, Friedrich I, Hoffmann MM, Huttinger M, Wieland H, Marz W. Competition of Abeta amyloid peptide and apolipoprotein E for receptor-mediated endocytosis. J Lipid Res. 1999; 40:447-55.

23. Saito H, Dhanasekaran $P$, Nguyen D, Baldwin F, Weisgraber KH, Wehrli S, Phillips MC, Lund-Katz S. Characterization of the heparin binding sites in human apolipoprotein E. J Biol Chem. 2003;278:14782-7.

24. Futamura M, Dhanasekaran P, Handa T, Phillips MC, Lund-Katz S, Saito H. Two-step mechanism of binding of apolipoprotein $\mathrm{E}$ to heparin: implications for the kinetics of apolipoprotein E-heparan sulfate proteoglycan complex formation on cell surfaces. J Biol Chem. 2005;280:5414-22

25. Brunden KR, Richter-Cook NJ, Chaturvedi N, Frederickson RC. pH-dependent binding of synthetic beta-amyloid peptides to glycosaminoglycans. Neurochem. 1993;61:2147-54.

26. Verghese PB, Castellano JM, Garai K, Wang Y, Jiang H, Shah A, Bu G, Frieden C, Holtzman DM. ApoE influences amyloid-beta (Abeta) clearance despite minimal apoE/Abeta association in physiological conditions. Proc Natl Acad Sci U S A. 2013;110:E1807-16.

27. Boehm-Cagan A, Michaelson DM. Reversal of apoE4-driven brain pathology and behavioral deficits by bexarotene. J Neurosci. 2014;34:7293-301.

28. Innerarity TL, Mahley RW. Enhanced binding by cultured human fibroblasts of apo-E-containing lipoproteins as compared with low density lipoproteins. Biochemistry. 1978;17:1440-7.

29. Beisiegel U, Weber W, Ihrke G, Herz J, Stanley KK. The LDL-receptor-related protein, LRP, is an apolipoprotein E-binding protein. Nature. 1989;341:162-4.

30. Kowal RC, Herz J, Goldstein JL, Esser V, Brown MS. Low density lipoprotein receptor-related protein mediates uptake of cholesteryl esters derived from apoprotein E-enriched lipoproteins. Proc Natl Acad Sci U S A. 1989:86:5810-4

31. Mahley RW, Huang Y. Apolipoprotein E: from atherosclerosis to Alzheimer's disease and beyond. Curr Opin Lipidol. 1999;10:207-17.

32. Poon GM, Gariepy J. Cell-surface proteoglycans as molecular portals for cationic peptide and polymer entry into cells. Biochem Soc Trans. 2007:35:788-93.

33. Kanekiyo T, Zhang J, Liu Q, Liu CC, Zhang L, Bu G. Heparan sulphate proteoglycan and the low-density lipoprotein receptor-related protein 1 constitute major pathways for neuronal amyloid-beta uptake. J Neurosci. 2011:31:1644-51.

34. Holmes BB, DeVos SL, Kfoury N, Li M, Jacks R, Yanamandra K, Ouidja MO, Brodsky FM, Marasa J, Bagchi DP, et al. Heparan sulfate proteoglycans mediate internalization and propagation of specific proteopathic seeds. Proc Natl Acad Sci U S A. 2013;110:E3138-47.

35. Reinhard C, Borgers M, David G, De Strooper B. Soluble amyloid-beta precursor protein binds its cell surface receptor in a cooperative fashion with glypican and syndecan proteoglycans. J Cell Sci. 2013;126:4856-61.

36. Broekelmann TJ, Kozel BA, Ishibashi H, Werneck CC, Keeley FW, Zhang L, Mecham RP. Tropoelastin interacts with cell-surface glycosaminoglycans via its COOH-terminal domain. J Biol Chem. 2005:280:40939-47.

37. Williams TL, Serpell LC. Membrane and surface interactions of Alzheimer's Abeta peptide-insights into the mechanism of cytotoxicity. FEBS J. 2011;278:3905-17

38. Pozueta J, Lefort R, Shelanski ML. Synaptic changes in Alzheimer's disease and its models. Neuroscience. 2013;251:51-65.

39. Snyder EM, Nong Y, Almeida CG, Paul S, Moran T, Choi EY, Nairn AC, Salter MW, Lombroso PJ, Gouras GK, Greengard P. Regulation of NMDA receptor trafficking by amyloid-beta. Nat Neurosci. 2005:8:1051-8.

40. Renner M, Lacor PN, Velasco PT, Xu J, Contractor A, Klein WL, Triller A. Deleterious effects of amyloid beta oligomers acting as an extracellular scaffold for mGluR5. Neuron. 2010;66:739-54. 
41. Lauren J, Gimbel DA, Nygaard HB, Gilbert JW, Strittmatter SM. Cellular prion protein mediates impairment of synaptic plasticity by amyloid-beta oligomers. Nature. 2009;457:1128-32.

42. Watanabe N, Araki W, Chui DH, Makifuchi T, Ihara Y, Tabira T. Glypican-1 as an Abeta binding HSPG in the human brain: its localization in DIG domains and possible roles in the pathogenesis of Alzheimer's disease. FASEB J. 2004;18:1013-5

43. Cheng F, Ruscher K, Fransson LA, Mani K. Non-toxic amyloid beta formed in the presence of glypican-1 or its deaminatively generated heparan sulfate degradation products. Glycobiology. 2013;23:1510-9.

44. Naslund J, Haroutunian V, Mohs R, Davis KL, Davies P, Greengard P, Buxbaum JD. Correlation between elevated levels of amyloid beta-peptide in the brain and cognitive decline. JAMA. 2000;283:1571-7.

45. Wang X, Zhao Y, Zhang X, Badie H, Zhou Y, Mu Y, Loo LS, Cai L, Thompson $\mathrm{RC}$, Yang $B$, et al. Loss of sorting nexin 27 contributes to excitatory synaptic dysfunction by modulating glutamate receptor recycling in Down's syndrome. Nat Med. 2013;19:473-80.

46. Bishop JR, Schuksz M, Esko JD. Heparan sulphate proteoglycans fine-tune mammalian physiology. Nature. 2007:446:1030-7

47. Fuentealba RA, Liu Q, Kanekiyo T, Zhang J, Bu G. Low density lipoprotein receptor-related protein 1 promotes anti-apoptotic signaling in neurons by activating Akt survival pathway. J Biol Chem. 2009;284:34045-53.

48. Kanekiyo T, Cirrito JR, Liu CC, Shinohara M, Li J, Schuler DR, Holtzman DM, Bu G. Neuronal clearance of amyloid-beta by endocytic receptor LRP1. J Neurosci. 2013;33:19276-83.

49. Kanekiyo T, Liu CC, Shinohara M, Li J, Bu G. LRP1 in brain vascular smooth muscle cells mediates local clearance of Alzheimer's amyloid-beta. J Neurosci. 2012;32:16458-65.

50. Kim J, Jiang H, Park S, Eltorai AE, Stewart FR, Yoon H, Basak JM, Finn MB, Holtzman DM. Haploinsufficiency of human APOE reduces amyloid deposition in a mouse model of amyloid-beta amyloidosis. J Neurosci. 2011;31:18007-12.

51. Bien-Ly N, Gillespie AK, Walker D, Yoon SY, Huang Y. Reducing human apolipoprotein E levels attenuates age-dependent Abeta accumulation in mutant human amyloid precursor protein transgenic mice. J Neurosci. 2012;32:4803-11.

52. Kim J, Eltorai AE, Jiang H, Liao F, Verghese PB, Stewart FR, Basak JM, Holtzman DM. Anti-apoE immunotherapy inhibits amyloid accumulation in a transgenic mouse model of Abeta amyloidosis. J Exp Med. 2012;209:2149-56

53. Liao F, Hori $Y$, Hudry E, Bauer AQ, Jiang H, Mahan TE, Lefton KB, Zhang TJ, Dearborn JT, Kim J, et al. Anti-ApoE antibody given after plaque onset decreases Abeta accumulation and improves brain function in a mouse model of Abeta amyloidosis. J Neurosci. 2014;34:7281-92.

54. Bergamaschini L, Rossi E, Storini C, Pizzimenti S, Distaso M, Perego C, De Luigi A, Vergani C, De Simoni MG. Peripheral treatment with enoxaparin, a low molecular weight heparin, reduces plaques and beta-amyloid accumulation in a mouse model of Alzheimer's disease. J Neurosci. 2004:24:4181-6.

55. Sandwall E, O'Callaghan P, Zhang X, Lindahl U, Lannfelt L, Li JP. Heparan sulfate mediates amyloid-beta internalization and cytotoxicity. Glycobiology. 2010;20:533-41.

56. Mucke L, Selkoe DJ. Neurotoxicity of amyloid beta-protein: synaptic and network dysfunction. Cold Spring Harb Perspect Med. 2012;2:a006338.

57. Lesne SE, Sherman MA, Grant M, Kuskowski M, Schneider JA, Bennett DA, Ashe $\mathrm{KH}$. Brain amyloid-beta oligomers in ageing and Alzheimer's disease. Brain. 2013;136:1383-98.

58. Liu CC, Kanekiyo T, Xu H, Bu G. Apolipoprotein E and Alzheimer disease: risk, mechanisms and therapy. Nat Rev Neurol. 2013;9:106-18.

59. Ma J, Yee A, Brewer HB Jr, Das S, Potter H. Amyloid-associated proteins alpha 1-antichymotrypsin and apolipoprotein E promote assembly of Alzheimer beta-protein into filaments. Nature. 1994;372:92-4.

60. Vance JE, Hayashi H. Formation and function of apolipoprotein E-containing lipoproteins in the nervous system. Biochim Biophys Acta. 1801;2010:806-18.

61. Shuvaev W, Laffont I, Siest G. Kinetics of apolipoprotein E isoforms-binding to the major glycosaminoglycans of the extracellular matrix. FEBS Lett. 1999:459:353-7.

62. Libeu CP, Lund-Katz S, Phillips MC, Wehrli S, Hernaiz MJ, Capila I, Linhardt RJ, Raffai RL, Newhouse YM, Zhou F, Weisgraber KH. New insights into the heparan sulfate proteoglycan-binding activity of apolipoprotein E. J Biol Chem. 2001;276:39138-44.
63. LaDu MJ, Falduto MT, Manelli AM, Reardon CA, Getz GS, Frail DE. Isoform-specific binding of apolipoprotein $\mathrm{E}$ to beta-amyloid. J Biol Chem. 1994;269:23403-6.

64. Wisniewski T, Golabek A, Matsubara E, Ghiso J, Frangione B. Apolipoprotein E: binding to soluble Alzheimer's beta-amyloid. Biochem Biophys Res Commun. 1993;192:359-65.

65. Cruchaga C, Kauwe JS, Nowotny P, Bales K, Pickering EH, Mayo K, Bertelsen S, Hinrichs A, Fagan AM, Holtzman DM, et al. Cerebrospinal fluid APOE levels: an endophenotype for genetic studies for Alzheimer's disease. Hum Mol Genet. 2012;21:4558-71.

66. Martinez-Morillo E, Hansson O, Atagi Y, Bu G, Minthon L, Diamandis EP, Nielsen HM. Total apolipoprotein E levels and specific isoform composition in cerebrospinal fluid and plasma from Alzheimer's disease patients and controls. Acta Neuropathol. 2014;127:633-43.

67. Brody DL, Magnoni S, Schwetye KE, Spinner ML, Esparza TJ, Stocchetti N, Zipfel GJ, Holtzman DM. Amyloid-beta dynamics correlate with neurological status in the injured human brain. Science. 2008;321:1221-4.

68. Shinohara M, Petersen RC, Dickson DW, Bu G. Brain regional correlation of amyloid-beta with synapses and apolipoprotein E in non-demented individuals: potential mechanisms underlying regional vulnerability to amyloid-beta accumulation. Acta Neuropathol. 2013;125:535-47.

69. Cramer PE, Cirrito JR, Wesson DW, Lee CY, Karlo JC, Zinn AE, Casali BT, Restivo JL, Goebel WD, James MJ, et al. ApoE-directed therapeutics rapidly clear beta-amyloid and reverse deficits in AD mouse models. Science. 2012;335:1503-6.

70. Fitz NF, Cronican A, Pham T, Fogg A, Fauq AH, Chapman R, Lefterov I, Koldamova R. Liver $X$ receptor agonist treatment ameliorates amyloid pathology and memory deficits caused by high-fat diet in APP23 mice. J Neurosci. 2010;30:6862-72.

71. Zhao J, Fu Y, Liu CC, Shinohara M, Nielsen HM, Dong Q, Kanekiyo T, Bu G. Retinoic acid isomers facilitate apolipoprotein E production and lipidation in astrocytes through the RXR/RAR pathway. J Biol Chem. 2014;289:11282.

72. Morikawa M, Fryer JD, Sullivan PM, Christopher EA, Wahrle SE, DeMattos RB, O'Dell MA, Fagan AM, Lashuel HA, Walz T, et al. Production and characterization of astrocyte-derived human apolipoprotein E isoforms from immortalized astrocytes and their interactions with amyloid-beta. Neurobiol Dis. 2005;19:66-76.

73. Krul ES, Tikkanen MJ, Schonfeld G. Heterogeneity of apolipoprotein E epitope expression on human lipoproteins: importance for apolipoprotein $E$ function. J Lipid Res. 1988;29:1309-25.

74. DeMattos RB, Curtiss LK, Williams DL. A minimally lipidated form of cell-derived apolipoprotein $\mathrm{E}$ exhibits isoform-specific stimulation of neurite outgrowth in the absence of exogenous lipids or lipoproteins. J Biol Chem. 1998:273:4206-12

75. Melman L, Cao ZF, Rennke S, Marzolo MP, Wardell MR, Bu G. High affinity binding of receptor-associated protein to heparin and low density lipoprotein receptor-related protein requires similar basic amino acid sequence motifs. J Biol Chem. 2001;276:29338-46.

76. Li J, Kanekiyo T, Shinohara M, Zhang Y, Ladu MJ, Xu H, Bu G. Differential regulation of amyloid-beta endocytic trafficking and lysosomal degradation by apolipoprotein E isoforms. J Biol Chem. 2012;287:44593-601.

\section{Submit your next manuscript to BioMed Central and we will help you at every step:}

- We accept pre-submission inquiries

- Our selector tool helps you to find the most relevant journal

- We provide round the clock customer support

- Convenient online submission

- Thorough peer review

- Inclusion in PubMed and all major indexing services

- Maximum visibility for your research

Submit your manuscript at www.biomedcentral.com/submit 